\title{
Minimising Excessive Energy Consumption in Schools While Maintaining Optimal Air Quality
}

\author{
Sven Hallin \\ London-Loughborough Centre for Doctoral Research in Energy Demand, School of Civil and Building Engineering, \\ Loughborough University, Loughborough, UK \\ Email: hallinsf@hotmail.co.uk
}

How to cite this paper: Hallin, S. (2017) Minimising Excessive Energy Consumption in Schools While Maintaining Optimal Air Quality. Open Journal of Optimization, 6, 149-163.

https://doi.org/10.4236/ojop.2017.64010

Received: October 20, 2017

Accepted: December 1, 2017

Published: December 4, 2017

Copyright (c) 2017 by author and Scientific Research Publishing Inc. This work is licensed under the Creative Commons Attribution International License (CC BY 4.0).

http://creativecommons.org/licenses/by/4.0/

(c) (i) Open Access

\begin{abstract}
This paper presents an assessment of how to minimise excessive energy consumption in a case study school classroom while maintaining optimal indoor air quality. Using mixed method research with qualitative interview data supporting quantitative key data measurements, essential primary data was extracted from temperature and carbon dioxide monitoring equipment in the classroom. This was then used, along with other ancillary data, to develop an IES computer model of the classroom as a "base case" reflecting existing energy consumption, temperatures and $\mathrm{CO}_{2}$ levels. Eight different interventions were then developed and modelled which reflected improved energy supply and a variety of ventilation strategies. The results show that adequate control and design of energy supply systems is critical to minimising excessive energy consumption, and that adequate internal air quality is achievable through a variety of low cost strategies.
\end{abstract}

\section{Keywords}

Energy, Design, Air Quality, Schools, Ventilation, Modelling, Measurements

\section{Introduction}

It is worth noting that the reason this research is not as recent as it could be, is because it was planned that a follow-up assessment could be done at the school under study to validate the findings. Before a follow-up could be carried out however, developers purchased the school on the condition that they would build a new school elsewhere. Despite this, the findings from the original research could prove very useful for future researchers concerned with why very many schools use excessive amounts of energy and still manifest poor air quality.

Indeed indoor air quality in schools has long been an area of concern by both 
government and private individuals. This is because poor air quality can have impacts on health, productivity and comfort [1]. A study by Dasgupta et al. [2] shows newly built schools are failing to meet basic performance criteria in relation to efficient energy consumption and good environmental air quality. The cause is largely due to lack of adequate design. It asserts that the engineering science of designing learning environments is remarkably undeveloped. While the research does not suggest any new design principles, it indicates behavioural aspects are responsible for significant energy use in schools. Technological design solutions will only be successful when occupants of a building are committed and informed on how to use energy-efficient systems in an appropriate way [3].

The results of another study [4] were that $36 \%$ of all daily average values of carbon dioxide in the monitored classrooms exceeded 1500 ppm, which exceeds the government's recommended guidelines, as set out in Building Bulletin 101 which is quoted in Approved Documents F and L2 (amended 2006) as a means of compliance with Regulations F1 and L of the Building Regulations for school buildings [5]. Research has shown that recommended $\mathrm{CO}_{2}$ levels are often exceeded [6] [7].

Daisey et al. [8] report that $\mathrm{CO}_{2}$ and ventilation data indicate that ventilation is inadequate in many classrooms, possibly leading to negative health effects. They assert studies have shown that these negative health symptoms, such as asthma and sick building syndrome (SBS) have a causal relationship with volatile organic compounds (VOC's) such as formaldehyde and allergens in deposited dust, fungi and bacteria. SBS is a combination of ailments associated with a building's poor indoor air quality [9].

Using $\mathrm{CO}_{2}$ as a proxy for the variety of compounds that cause Sick Building Syndrome, Fisk [1] determined that excess carbon dioxide can lead to an increase in occupants experiencing this syndrome. He discovered when the average $\mathrm{CO}_{2}$ levels were below $800 \mathrm{ppm}$ within office environments there were significantly fewer cases of respiratory illness, asthmatic problems and ailments associated with mucous membrane build up.

While some other studies [10] concentrate on poor indoor air quality affecting children's health, Coley's research on ventilation rates and cognitive performance in UK schools [11] concludes that the performance of children is significantly slower (by an average of 5\%) when the level of $\mathrm{CO}_{2}$ in the classrooms is over $1500 \mathrm{ppm}$. The conclusions of this study were supported by earlier research [12], which established that classrooms with high $\mathrm{CO}_{2}$ levels could have long run detrimental effects on learning and attainment, as students were less able to concentrate and pay attention.

Parsons [13] indicates that the thermal environment of buildings directly affects the thermal sensation and comfort of the occupants as well as their psychological and behavioural responses to increasing temperature, atmospheric pressure and humidity. These factors impact on people's psychological reactions such as temper, anxiety, aggression and depression. The relationship between 
thermal comfort and IAQ was examined as part of a study [14] of a naturally ventilated classroom. In this research the room had adequate ventilation available to meet building regulations but it could not always be used without affecting thermal comfort. Pupils and staff were found to control the ventilation to satisfy thermal comfort rather than ensure adequate internal air quality.

Given these findings, as schools have four times higher occupancy levels per unit area than office buildings [15], they represent an important area of research into optimum levels of Indoor Air Quality (IAQ), temperature and energy use. The results of this research show that adequate control and design of energy supply systems is critical to minimising excessive energy consumption, and that adequate internal air quality is achievable through a variety of low cost strategies.

\section{Research Methodology}

This research used IES modelling software [16] to create a "base case" of the classroom under study, reproducing a reasonable approximation of existing energy consumption, temperatures and $\mathrm{CO}_{2}$ levels. In order to create a realistic model, the classroom was characterised with regard to the key elements which would be used to provide the model parameters. As energy use in buildings depends on the interaction between the occupants [17], the building fabric [18], the way energy is delivered [19] and the local climate [20], these four factors were considered when characterising the classroom under study.

A representation of the classroom and its attributes are shown in Figure 1.

Occupancy patterns in Table 1 were determined by discussion with the school bursar.

The case study classroom was in the original part of the school. After 1968 the building was extended to incorporate new classrooms and reception areas.

The school location was in a quiet rural village (Latitude: 52.7; Longitude: -1.13 ) around 8 miles south of Loughborough.

The building foundations were not visible but were assumed to be strip foundations under the load bearing walls. Typically for this period the foundations would be in the form of brick footings, three brick lengths at the base $(680 \mathrm{~mm})$ stepped up to the structural wall. The depth of the building foundation was assumed to be adequate as there was no evidence of significant (greater than 5 $\mathrm{mm}$ ) cracking in the brickwork [21]. Rebuilt in 1871 [22], the wall construction was of $350 \mathrm{~mm}$ solid brick in an English Bond pattern. The condition was generally good, with only slight evidence of spalling (flaking of the brickwork from weathering). The roof was of a pitched design. The roof space above the classroom was inaccessible but it was assumed to be of a traditional wood rafter and purlin construction. The roof tiles were made of slate. The floor was made of wood and ventilated underneath by air bricks set in the building's damp proof course. Larger ventilation grills straddled the engineering and normal brickwork on the northern and western side of the north facing wall. There was a possibility that this configuration could cause thermal bridging as well as the risk of rising 

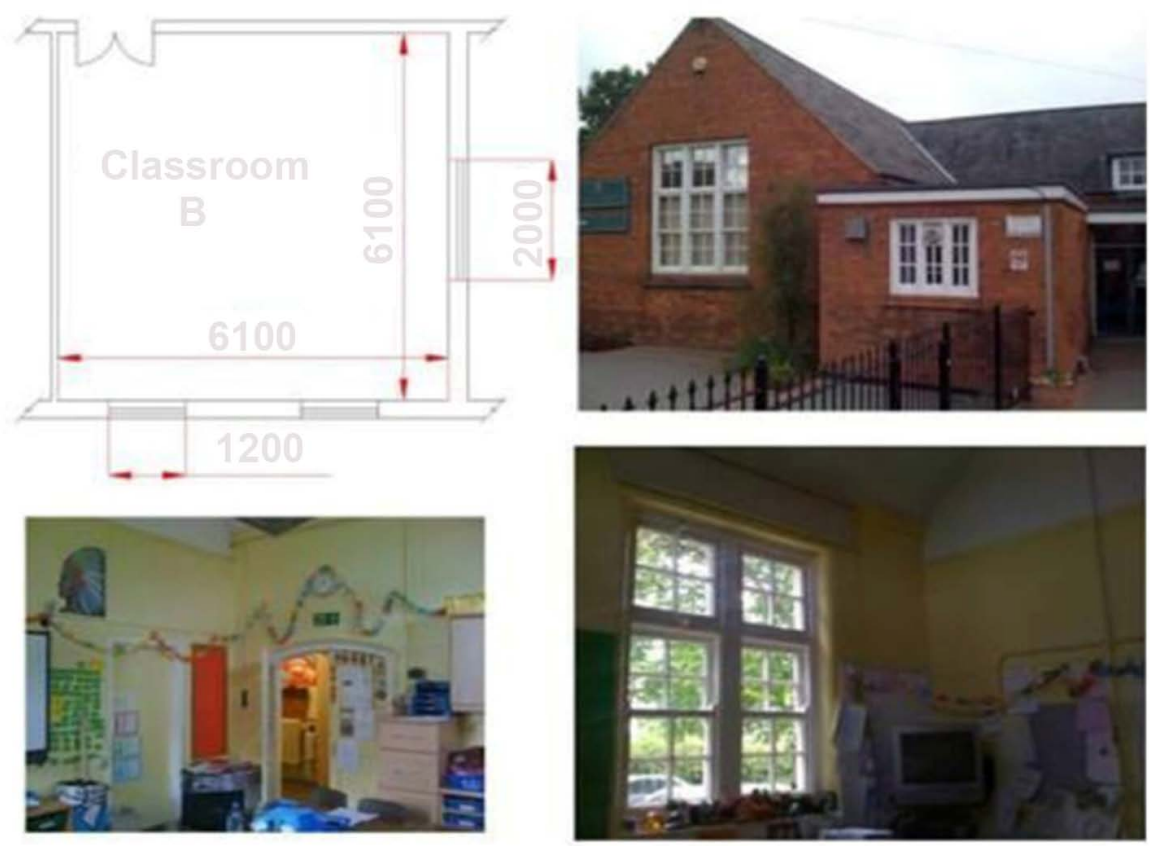

Figure 1. Case study classroom.

Table 1. Occupancy and break times during the school day.

\begin{tabular}{ll}
\hline Occupancy times & \multicolumn{1}{c}{$09: 00-15: 00$} \\
\hline \multirow{2}{*}{ Break times } & Assembly: 9:10 - 9:30; Morning break: 10:35 - 10:55; Lunch 12 - 13:15. \\
& Keystage 1 (Classes D and E) also have a break between 14:30 and 14:45. \\
\hline
\end{tabular}

damp. There was also some evidence of possible damp at floor level below the window on the north wall.

The school heating system consisted of four natural gas fired boilers in parallel which provided heat to a standard low pressure hot water system. The boilers provided heat into a pumped main circuit and combined header system and were programmed to maintain a flow temperature at the header of approximately $80^{\circ} \mathrm{C}$. From the header, water was pumped to each of three school heating zones, and then returned to the header through return pipes. The case study classroom was in the East zone.

The East zone was a constant temperature type circuit with fan convectors for heating the rooms or common areas.

There was a control panel in the boiler room which automatically controlled the number of boilers required to be in operation and the activation of the pumps.

Zone heating was done with "intelligent" controls. Occupied time periods and a temperature set point were fixed on the system and the heating control "learned" the response of the building over the heating season. Thus, on a cold morning the heating might have come on earlier than normal and turn off later than usual, and vice versa when conditions were warm.

The assessed classroom was heated in the northwest corner of the room by a 
heater with two fan convectors powered by one $75 \mathrm{~W}$ twin shaft motor. There was a temperature detector on the classroom wall near the internal door on the south side of the room. This was non-user adjustable and turned the convector fans off or on as required to maintain the correct room temperature. The reported space heating temperature set point for the room was $19^{\circ} \mathrm{C}$.

Electric power for the convector fans was controlled via the main heating control panel in the boiler room. The fans could not run (and thus the heating could not work) unless this control panel was switched on and programmed with the correct time. The usual heating clock settings for the classroom were to turn on at 07.30 and turn off at 15.00 , Monday to Friday. For the overall heating system, there was a minimum night/unoccupied temperature setting of $10^{\circ} \mathrm{C}$.

There was a winter, summer and holiday setting on the control panel. The winter setting ensured hot water and space heating was delivered at pre-set temperatures to the various school rooms. The summer setting turned off the space heating and just delivered required hot water. The holiday setting turned off both space and hot water heating.

The IES model used weather data from Nottingham/Watnall weather station, 29 miles away from the case study classroom. The data comprised an Example Weather Year (also known as a Test Reference Year), which is a single year of hourly data ( 8760 hours). This was selected to represent the range of weather patterns that would typically be found in a dataset covering the Nottingham weather station over the last 25 years.

The basis for developing Example Weather Years was formulated by the Chartered Institution of Building Services Engineers [23]. The intention of using this format was to allow a more practical simulation than using multi-year datasets, and also to create an equitable basis for comparisons of predicted energy consumption in different building designs.

Nottingham/Watnall was the closest weather station from which Example Weather Year data was available. The effect of unusually cold weather being responsible for the school's high energy use (which would not be taken account of by the IES model) was discounted, as the Display Energy Certificate at the school showed the previous two years energy consumption as similar or at higher levels than currently recorded for this research period.

Classroom temperature and $\mathrm{CO}_{2}$ data were recorded using the following:

1) A Hobo Pendant Temperature Data Logger (UA-001-08) was placed under the classroom whiteboard in the classroom, recording temperatures every $5 \mathrm{mi}$ nutes. The data from the hobo was downloaded at regular intervals onto Hoboware software and exported in CSV format onto an Excel spreadsheet.

2) Two Telaire 7001 Carbon Dioxide and Temperature Monitors were placed at opposite sides of the classroom. These recorded $\mathrm{CO}_{2}$ and temperature levels every 5 minutes. The data was downloaded at regular intervals onto Hoboware software and exported in CSV format onto an Excel spreadsheet.

3) A Hobo Pendant Temperature Data Logger (UA-001-08) was placed outside the school building, behind a wall near the school entrance and the data 
recorded.

The school heating manual was studied and informal interviews were conducted with staff, pupils and the heating engineer contracted to service the school heating system. The purpose of these interviews was to gather information relating to energy use, temperature levels and Indoor air quality at the school as well as any other information that might be relevant to the study.

\section{The IES "Base Case" Model}

The case study base case is shown in Figure 2 .

\subsection{Model Assumptions}

The model was constructed using the dimensions shown in Table 2: Case Study Classroom.

The U-Values of the main elements are summarised in Table 3.

\subsection{Classroom Temperature Levels}

The classroom temperatures were measured from the 13th January throughout the following months until the end of May. The winter/summer switchover time was the end of March. The intended set point temperature was clearly not being satisfied, with the classroom reaching consistently higher temperatures during school hours. To verify this, a winter average occupied temperature of $22.3^{\circ} \mathrm{C}$ was calculated from the $20^{\text {th }}$ February to $30^{\text {th }}$ March. This calculation was an average of occupied times only (Figure 3 ).

In the light of this data, there was further discussion with the school. It was confirmed that the case study classroom set point temperature should be $19^{\circ} \mathrm{C}$. However, as classrooms in the school seemed to become too warm which affected the thermal comfort of the occupants, the heating pumps were sometimes turned off at night in order to try and alleviate this situation. In addition, the complexity of the heating system was not fully understood by staff at the school, which meant there was a lack of certainty as to how to overcome the problem of overheating.

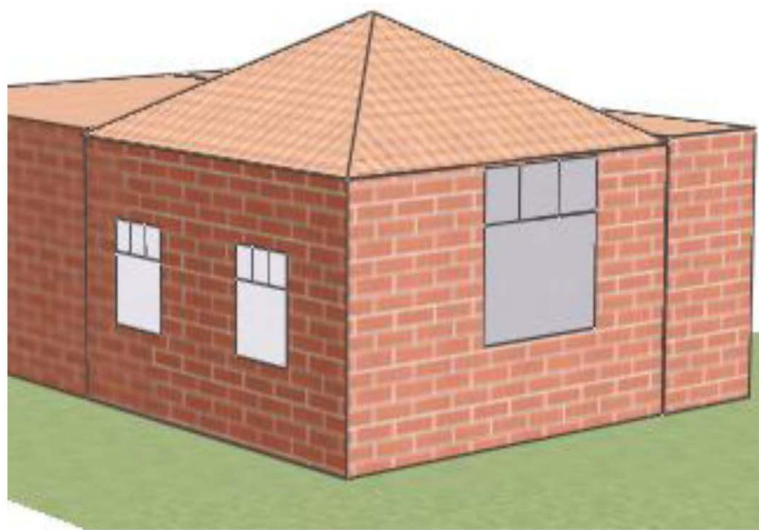

Figure 2. IES base case model. 


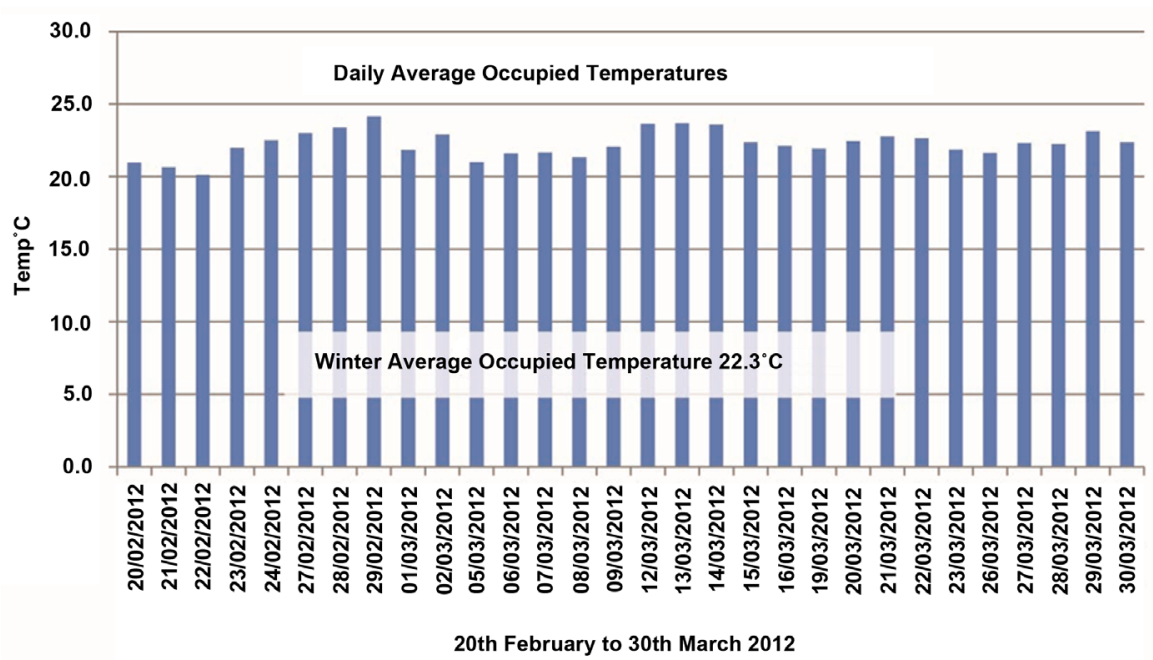

Figure 3. Classroom winter average temperature.

Table 2. Model room dimensions.

\begin{tabular}{cc}
\hline Height & $4.06 \mathrm{~m}$ \\
Width & $6.50 \mathrm{~m}$ \\
Length & $6.50 \mathrm{~m}$ \\
Small windows & $1.20 \mathrm{~m} \times 1.60 \mathrm{~m}$ (times 2$)$ \\
Large window & $2.30 \mathrm{~m} \times 2.55 \mathrm{~m}$ \\
Corridor door & $1.96 \mathrm{~m} \times 1.25 \mathrm{~m}$ \\
Connecting door (sealed) & $1.60 \mathrm{~m} \times 0.73 \mathrm{~m}$ \\
\hline
\end{tabular}

Table 3. Component U-values.

\begin{tabular}{ccc}
\hline Component & U-value & Comment \\
\hline External walls & 1.7045 & Solid wall construction \\
Internal walls & 1.6896 & IES generic \\
Ceiling & 1.2585 & Timber joist internal \\
Floor & 0.6278 & Suspended, timber \\
Doors & 2.1944 & Wooden door, generic \\
External windows & 4.6599 & Single glazed/heavy frame \\
\hline
\end{tabular}

The heating manual confirmed that the "intelligent" nature of the heating system was designed so that human short term intervention was unnecessary. Once the system is set up it should automatically adjust to internal and external temperature conditions in order to maintain desired room temperatures.

As the system did not seem to be working as it should, the researcher had a discussion with the heating engineer contracted to service the school heating system. It was reported that on a previous service the set point in the case study classroom (not visible to occupants) was around $23^{\circ} \mathrm{C}$, and it was left at this level 
as adjusting it to $19^{\circ} \mathrm{C}$ without specific instructions to do so might result in a complaint from the school which would necessitate a further service visit which could not then be charged for.

With the actual temperature data and the interview evidence obtained, two factors leading to excessive energy consumption were hypothesised:

1) The "intelligent" heating system is affected by human intervention (this is also noted in the manual). Human action which may be intended to reduce overheating and save energy, such as turning off the heating pumps may be counterproductive as the intelligent heating system may overcompensate to cold conditions when the pumps are on again (for example, when the night temperature falls below $10^{\circ} \mathrm{C}$ ).

2) The case study classroom setpoint may be too high (at $22.3^{\circ} \mathrm{C}$, as measured, instead of $\left.19^{\circ} \mathrm{C}\right)$.

Given the above factors, it was decided to produce a "base case" IES model of the classroom using a set point of $22.3^{\circ} \mathrm{C}$.

\subsection{Classroom $\mathrm{CO}_{2}$ Levels}

The classroom $\mathrm{CO}_{2}$ levels were also measured from the 13th January and throughout the following months until the end of May. The $\mathrm{CO}_{2}$ data monitors which were used in this research only record to a maximum level of $2499 \mathrm{ppm}$ and this was reached at some point on most days in the data represented. Because the actual maximum levels are unknown, working out accurate average levels is not possible.

However a minimum average $\mathrm{CO}_{2}$ level could be calculated to show that it exceeded the recommended average of 1500 ppm (see Figure 4).

\subsection{Internal Gains}

Table 4 shows internal heat gains in the case study classroom.

The IES default internal gains for people was accepted as it is supported by research [24] which postulates an average man's heat loss rate as approximately $100 \mathrm{~W}$

The internal gain for the eight $75 \mathrm{~W}$ fluorescent lights was calculated from the GE lighting website

[http://www.gelighting.com/LightingWeb/na/resources/tools].

The machinery internal gain was broken down as follows in Table 5.

\subsection{Ventilation}

Table 6 outlines classroom air exchanges.

Infiltration was calculated on the $16^{\text {th }}$ of March using the natural logarithm formula [26]:

$$
\operatorname{Ln}\left[\left(C_{\min }-C_{0}\right) /\left(C_{\max }-C_{0}\right)\right]
$$

where:

$C_{\max }=$ Initial highest daily $\mathrm{CO}_{2}$ concentration 2499 ppm; 


\section{Daily Average Occupied $\mathrm{CO}_{2}$ Levels}

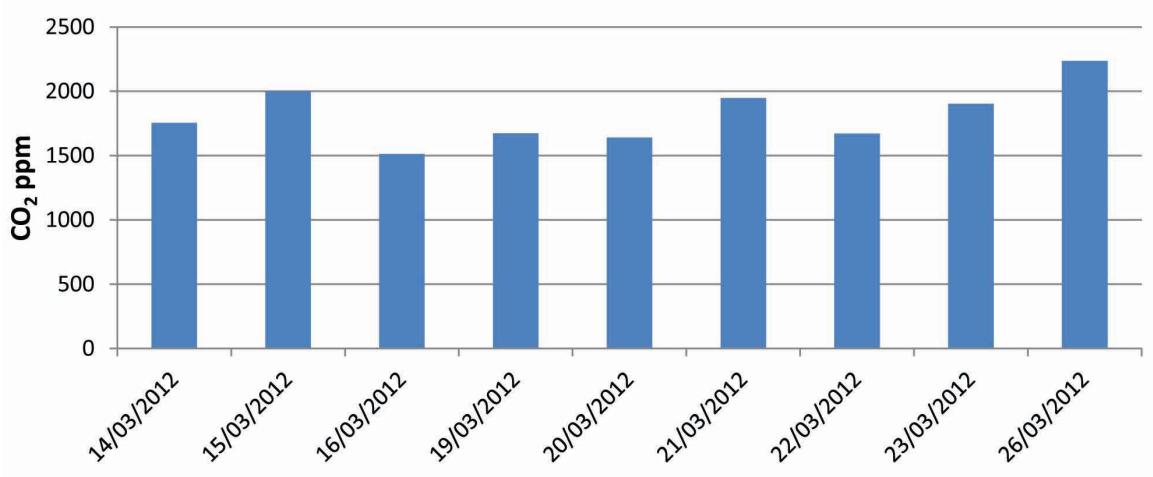

14th March to 26th March Occupied $\mathrm{CO}_{2}$ Levels

Figure 4. Average occupied carbon dioxide levels.

Table 4. Internal gains.

\begin{tabular}{|c|c|c|c|c|}
\hline \multicolumn{5}{|c|}{ Internal gains } \\
\hline People & $90 \mathrm{~W} / \mathrm{p}$ (sensible) & $60 \mathrm{~W} / \mathrm{p}$ (latent) & $\begin{array}{c}30 \text { students \& } 1 \\
\text { teacher }\end{array}$ & $\begin{array}{c}\text { Annual } \\
\text { occupancy profile }\end{array}$ \\
\hline Machinery & $300 \mathrm{~W}$ & $\begin{array}{c}\text { Radiant } \\
\text { fraction }=0.22\end{array}$ & $\begin{array}{l}\text { See breakdown } \\
\text { below }\end{array}$ & $\begin{array}{c}\text { Annual } \\
\text { occupancy profile }\end{array}$ \\
\hline $\begin{array}{c}\text { Fluorescent } \\
\text { lighting }\end{array}$ & $14.29 \mathrm{~W} / \mathrm{m}^{2}$ & $\begin{array}{c}\text { Radiant } \\
\text { fraction }=0.45\end{array}$ & $\begin{array}{l}\text { See breakdown } \\
\text { below }\end{array}$ & $\begin{array}{c}\text { Annual } \\
\text { occupancy profile }\end{array}$ \\
\hline
\end{tabular}

Table 5. Classroom equipment heat gains.

\begin{tabular}{ccc}
\hline Equipment & Convected gain & Source of data \\
\hline Computers & $55 \mathrm{~W}$ & {$[25]$} \\
Monitor & $70 \mathrm{~W}$ & heating engineer \\
Projector & $100 \mathrm{~W}$ & \\
Convector fan motor & $75 \mathrm{~W}$ & \\
Total & $300 \mathrm{~W}$ & \\
\hline
\end{tabular}

Table 6. Air exchanges.

\begin{tabular}{ccc}
\hline & Air exchanges & \\
\hline Infiltration & 1.620 ach external air & See calculation below \\
\hline Macrflo linked ventilation & $\begin{array}{c}33 \% \text { openable area; Max open angle } \\
25^{\circ} \text {; Opening threshold } 21^{\circ} \mathrm{C}\end{array}$ & $\begin{array}{c}\text { Window opening annual } \\
\text { profile (based on observation) }\end{array}$ \\
\hline
\end{tabular}

$C_{\min }=$ Lowest daily $\mathrm{CO}_{2}$ concentration $815 \mathrm{ppm}$;

$C_{0}=$ External $\mathrm{CO}_{2}$ concentration $400 \mathrm{ppm} \mathrm{[27];}$

This gave an Air Change per Hour of 1.62 (ach).

\section{Modelling Results and Interventions}

This section of the paper presents an overview of how the "Base Case" model 
compared with the measured temperatures and internal air quality (IAQ) of the case study classroom. It then summarises the interventions that were modelled to optimise temperature, IAQ and energy use in the classroom.

\subsection{Energy Use}

A Base Case and DEC comparison of energy use is shown in Table 7.

The IES model is simulating energy use for one classroom which is just $42 \mathrm{~m}^{2}$ of a school total floor area of $1469 \mathrm{~m}^{2}(2.8 \%)$, so it is likely other areas of the school will have variation in their energy use given a variety of different spatial dimensions, uses and building fabrics. Taking this into account, the simulation result for energy use can be considered to be reasonably accurate.

\subsection{Indoor Air Quality}

Simulation set point was at $22.3^{\circ} \mathrm{C}$, with window opening threshold at $21^{\circ} \mathrm{C}$.

The simulated $\mathrm{CO}_{2}$ levels in Figure 5 can be accepted as reasonable, as established levels could not be measured beyond $2499 \mathrm{ppm}$.

\subsection{Interventions}

All the interventions in Figure 6 assume the heating system is corrected to reliably supply space heating to the classroom at $19^{\circ} \mathrm{C}$ during occupied hours, and the window/ventilation opening profile is changed to work automatically according to a set profile. This profile varies with each intervention to reflect various ventilation strategies. A large number of combinations of automatic window opening were modelled, with the optimum combinations included in the results. In general the interventions assume that approximately a third of available existing windows will open slowly to their maximum opening window angle between the occupied times of 09.00 and 15.15 . The opening threshold is $18.99^{\circ} \mathrm{C}$ for this one third (which include interventions with vents, plenums or rooflights) and $21^{\circ} \mathrm{C}$ for the remaining window openings. Window opening starts when $\mathrm{CO}_{2}$ levels reach $850 \mathrm{ppm}$ and continues until windows are fully open when $\mathrm{CO}_{2}$ levels reach $950 \mathrm{ppm}$. When $\mathrm{CO}_{2}$ levels drop below $950 \mathrm{ppm}$ windows begin to close, and will fully close when $\mathrm{CO}_{2}$ levels reach $850 \mathrm{ppm}$.

The summary of interventions in Table 8 compares air quality and energy use.

\section{Discussion}

This research confirms an important finding from previous work [2] [3], notably that heating system design has a critical role to play in optimising energy use. Designs that limit the occupants' ability to understand how the heating system is performing are inviting an insufficient response by those occupants when the system malfunctions. This research shows how expensive this can be in energy use terms, where the case study school is using $50 \%$ more energy than the optimum level.

Control systems are also critical. Systems which are designed to be automatic and do not require human intervention in day to day use, need to be easily 


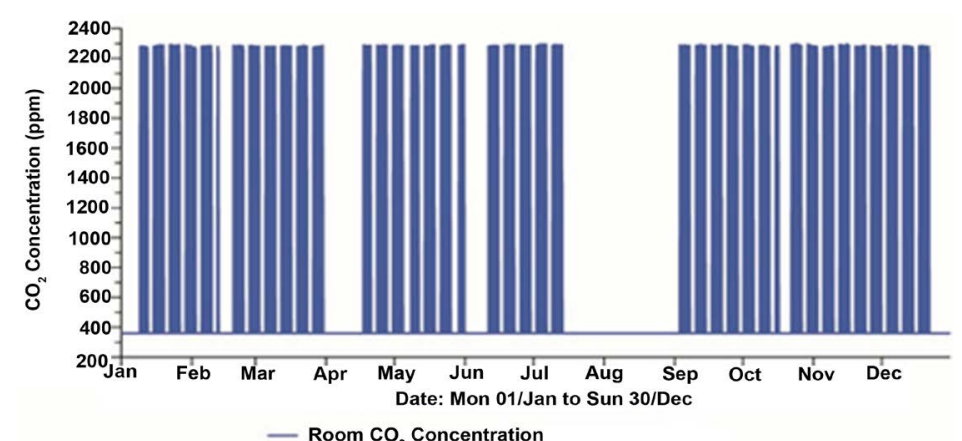

Figure 5. Case study classroom $\mathrm{CO}_{2}$ concentration (IES model).
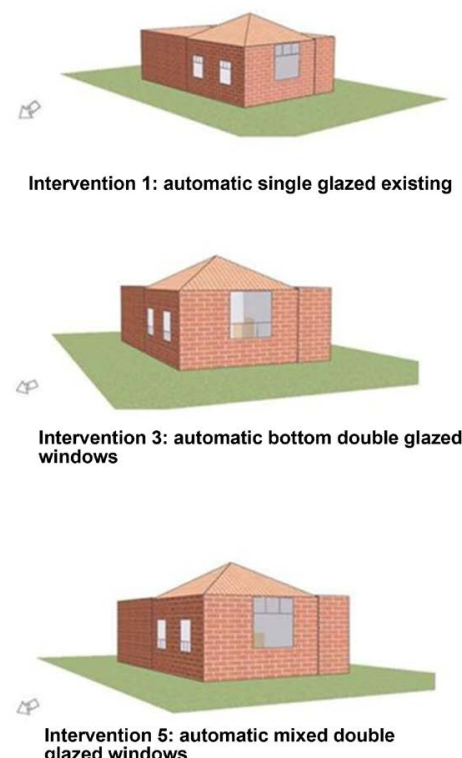
glazed windows

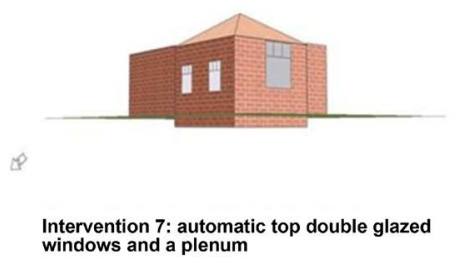

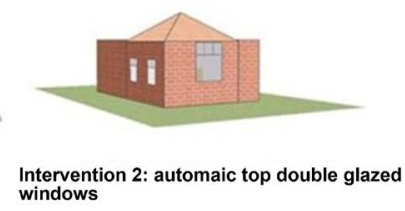
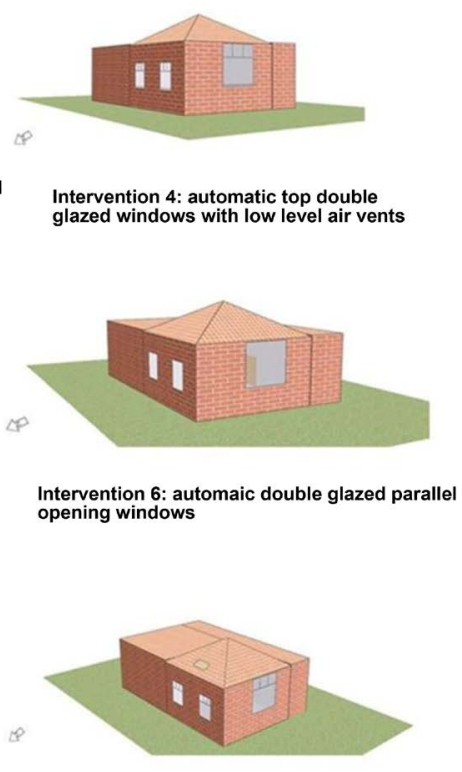

Intervention 8: automatic top double glazed windows with a rooflight and ceiling ventilation

Figure 6. Interventions 1 to 8 .

Table 7. Base case \& DEC comparison.

\begin{tabular}{cccc}
\hline & $\begin{array}{c}\text { Space heating (Gas) } \\
\mathrm{kWh} / \mathrm{m}^{2} / \text { year }\end{array}$ & $\begin{array}{c}\text { Electricity } \\
\mathrm{kWh} / \mathrm{m}^{2} / \text { year }\end{array}$ & $\begin{array}{c}\text { Total energy } \\
\mathrm{kWh} / \mathrm{m}^{2} / \text { year }\end{array}$ \\
\hline $\begin{array}{c}\text { Display energy } \\
\text { certificate (DEC) }\end{array}$ & 248 & 58 & 306 \\
$\begin{array}{c}\text { Base case IES Apache } \\
\text { simulation }\end{array}$ & 279 & 36 & 315 \\
\hline
\end{tabular}

understood by whoever is in charge of the heating system. There needs to be awareness of when there is a system malfunction and how it can be corrected. In this particular case study it is arguable that the space heating system is "over 
Table 8. Summary of interventions.

\begin{tabular}{|c|c|c|c|c|c|}
\hline & $\begin{array}{c}\text { Space heating } \\
\text { (Gas) } \mathrm{kWh} / \mathrm{m}^{2} / \text { year }\end{array}$ & $\begin{array}{c}\text { Electricity } \\
\mathrm{kWh} / \mathrm{m}^{2} / \text { year }\end{array}$ & $\begin{array}{l}\text { Total energy } \\
\mathrm{kWh} / \mathrm{m}^{2} / \text { year }\end{array}$ & Air quality $\left(\mathrm{CO}_{2}\right)$ & Comment \\
\hline $\begin{array}{l}\text { Display energy } \\
\text { certificate (DEC) }\end{array}$ & 248 & 58 & 306 & N/A & \\
\hline $\begin{array}{l}\text { Base case IES Apache } \\
\text { simulation }\end{array}$ & 279 & 36 & 315 & $>1500 \mathrm{ppm}$ & $\begin{array}{c}\text { Insufficient internal air } \\
\text { quality (IAQ) }\end{array}$ \\
\hline $\begin{array}{l}\text { IES intervention } 1 \\
\text { automatic single glazed } \\
\text { existing windows }\end{array}$ & 195 & 36 & 231 & $1441 \mathrm{ppm}$ & $\begin{array}{l}\text { Meets BB101 requirements } \\
\text { Energy saving is } 27 \%\end{array}$ \\
\hline $\begin{array}{c}\text { IES intervention } 2 \\
\text { automatic top double glazed } \\
\text { windows }\end{array}$ & 165 & 36 & 201 & $1437 \mathrm{ppm}$ & $\begin{array}{c}\text { Slightly better IAQ than } 1 \\
\text { Energy saving is } 36 \%\end{array}$ \\
\hline $\begin{array}{c}\text { IES intervention } 3 \\
\text { automatic bottom double } \\
\text { glazed windows }\end{array}$ & 164 & 36 & 200 & 1445 ppm & $\begin{array}{c}\text { Slightly worse IAQ than } 1 \text { \& } \\
\text { 2; Energy saving is } 36 \%\end{array}$ \\
\hline $\begin{array}{c}\text { IES intervention } 4 \\
\text { automatic top double glazed } \\
\text { windows with low level air } \\
\text { vents }\end{array}$ & 183 & 36 & 219 & 1307 ppm & $\begin{array}{c}\text { Better IAQ than } 1,2,3,5, \& \\
7 \text {; Energy saving is } 30 \%\end{array}$ \\
\hline $\begin{array}{c}\text { IES intervention } 5 \\
\text { automatic mixed } \\
\text { double glazed windows }\end{array}$ & 162 & 36 & 198 & $1446 \mathrm{ppm}$ & $\begin{array}{l}\text { Similar IAQ to } 1 \& 2 \\
\text { Energy saving is } 37 \%\end{array}$ \\
\hline $\begin{array}{c}\text { IES intervention } 6 \\
\text { automatic double glazed } \\
\text { parallel opening windows }\end{array}$ & 212 & 36 & 248 & $1024 \mathrm{ppm}$ & $\begin{array}{l}\text { Excellent air quality } \\
\text { Energy saving is } 21 \%\end{array}$ \\
\hline $\begin{array}{c}\text { IES intervention } 7 \\
\text { automatic top double glazed } \\
\text { windows and a plenum }\end{array}$ & 263 & 36 & 299 & $1328 \mathrm{ppm}$ & $\begin{array}{l}\text { Good air quality } \\
\text { Energy saving is } 5 \%\end{array}$ \\
\hline $\begin{array}{l}\text { IES intervention } 8 \text { automatic } \\
\text { top double glazed windows } \\
\text { with a rooflight }\end{array}$ & 253 & 36 & 289 & 943 ppm & $\begin{array}{l}\text { The best air quality. } \\
\text { Energy saving is } 8 \%\end{array}$ \\
\hline
\end{tabular}

engineered" in the sense that it is too complicated for the occupants to use effectively. A simple way to correct this would be to deactivate the "intelligent" controls and replace the room thermostats with visible controls. If each teacher were asked to keep their classroom at $19^{\circ} \mathrm{C}$ (save for cold snaps, etc.) it would ensure an easily regulated heating system. The school has an eco-group of year 5 and 6 children who could be asked to monitor thermostat levels, allowing the children greater involvement in and a better understanding of how the school uses energy.

The outlined interventions all offer improvements to a differing degree in energy use and internal air quality in the classroom under study. The most suitable ventilation strategy depends on whether energy cost or air quality is given the higher priority. Ultimately there is some trade-off between energy cost and indoor air quality in all the outlined interventions. The potential energy savings achieved through proper heating system control can more than offset the cost of improved natural ventilation strategies.

This research is qualified by a number of limitations. The gathered data was limited to roughly a three month winter period. While this was considered satis- 
factory, a longer period of data gathering would have meant a greater degree of accuracy.

The data analysed is from one school classroom, and can not necessarily be assumed to be typical. Also, while it seems apparent from the measured data that the heating system was not performing in an optimal manner, it remains unknown at what level problems may have occurred. The level of valve control, the exact set point temperature settings, and the level of human intervention is not certain.

Given the substantial savings identified through correcting heating controls and the clear possibility of improving indoor air quality through automatic window opening, further research is justified to determine the extent to which schools around the UK could benefit from these interventions. An initial survey of Display Energy Certificates at UK schools would provide a good sample of those which are using excessive energy for their building type. Within this group, internal air quality could then be assessed.

\section{Conclusions}

This work has described how a case study classroom was characterised and modelled using IES computer simulation. Despite being a case study, it confirms the critical role design and control has in heating system performance, and describes a number of ways in which energy use, classroom temperature and internal air quality can be optimised. A number of low cost natural ventilation strategies can be adopted to ensure internal air quality is within regulatory guidelines.

An initial survey of Display Energy Certificates, which Godoy-Shimizu et al. [28] confirm are key to understanding energy use in UK schools, would provide a good sample of those which are using excessive energy for their building type. Within this group, energy delivery and indoor air quality could then be assessed.

Future research in the UK school sector is justified on the basis that there are large potential energy savings to be made.

\section{Acknowledgements}

This research was made possible by EPSRC support for the London-Loughborough Centre for Doctoral Research in Energy Demand, grant number EP/H009612/1. Thanks to Professor Malcolm Cook for his advice and support.

\section{References}

[1] Fisk, W. (2002) How IEQ Affects Health, Productivity. ASHRAE Journal, 44(5), 56-60.

[2] Dasgupta, A., Prodromou, A. and Mumovic, D. (2012) Operational versus Designed Performance of Low Carbon Schools in England: Bridging a Credibility Gap. HVAC\&R Research, 18(1-2), 37-50.

[3] UNEP (2007) Buildings and Climate Change: Status, Challenges and Opportunities. United Nations Environment Programme. 
http://wedocs.unep.org/handle/20.500.11822/7783

[4] Building Research Establishment (2006) Ventilation and Indoor Air Quality in Schools-Guidance Report 202825. ODPM, London.

http://dera.ioe.ac.uk/14496/1/ventilation\%20and\%20indoor\%20air\%20quality\%20in \%20schools\%20guidance\%20report\%20202825.pdf

[5] Department for Communities and Local Government (2006) The Building Regulations Approved Documents F, Ventilation.

https://www.gov.uk/government/uploads/system/uploads/attachment_data/file/468 871/ADF_LOCKED.pdf

[6] Mumovic, D., Davies, M., Ridley, I., Altamirano-Medina, H. and Oreszczyn, T. (2009) A Methodology for Post-Occupancy Evaluation of Ventilation Rates in Schools. Building Services Engineering Research \& Technology, 30(2), 143-152. https://doi.org/10.1177/0143624408099175

[7] Santamouris, M., Synnefa, A., Asssimakopoulos, M., Livada, I., Pavlou, K., Papaglastra, M., et al. (2008) Experimental Investigation of the Air Flow and Indoor Carbon Dioxide Concentration in Classrooms with Intermittent Natural Ventilation. Energy \& Buildings, 40(10), 1833-1843. https://doi.org/10.1016/j.enbuild.2008.04.002

[8] Daisey, J., Angell, W. and Apte, M. (2003) Indoor Air Quality, Ventilation and Health Symptoms in Schools: An Analysis of Existing Information. Indoor Air, 13(1), 53-64. https://doi.org/10.1034/j.1600-0668.2003.00153.x

[9] Godish, T. (2001) Indoor Environmental Quality. CRC Press, New York.

[10] Cartieaux, E., Rzepka, M. and Cuny, D. (2011) Indoor Air Quality in Schools. Archives de Pédiatrie, 18(7), 789-796. https://doi.org/10.1016/j.arcped.2011.04.020

[11] Coley, D. and Greeves, R. (2004) The Effect of Low Ventilation Rates on the Cognitive Function of a Primary School Class. Centre for Energy and the Environment, University of Exeter, Exeter.

[12] Coley, D. and Beisteiner, A. (2002) Carbon Dioxide Levels and Ventilation Rates in Schools. International Journal of Ventilation, 1, 45-52. https://doi.org/10.1080/14733315.2002.11683621

[13] Parsons, K. (2003) Human Thermal Environments. 2nd Edition, Taylor \& Francis, London.

[14] Griffiths, M. and Eftekhari, M. (2008) Control of CO2 in a Naturally Ventilated Classroom. Energy and Buildings, 40(4), 556-560. https://doi.org/10.1016/j.enbuild.2007.04.013

[15] Seppanen, O., Fisk, W. and Mendell, M. (1999) Association of Ventilation Rates and $\mathrm{CO}_{2}$ Concentrations with Health and Other Responses in Commercial and Institutional Buildings. Indoor Air, 9, 226-252. https://doi.org/10.1111/j.1600-0668.1999.00003.x

[16] Integrated Environmental Solutions, VE Pro Software (2011). http://www.iesve.com

[17] Monahan, S. and Gemmell, A. (2011) How Occupants Behave and Interact with Their Homes: The Impact on Energy Use, Comfort, Control and Satisfaction. IHS BRE Press on Behalf of the NHBC Foundation, Milton Keynes.

[18] Lomas, K.J. (2010) Carbon Reduction in Existing Buildings: A Transdisciplinary Approach. Building Research \& Information, 38(1), 1-11. https://doi.org/10.1080/09613210903350937

[19] Lowe, R. (2007) Technical Options and Strategies for Decarbonizing UK Housing. Building Research \& Information, 35(4), 412-425. https://doi.org/10.1080/09613210701238268 
[20] Reinders, A., Vringer, K. and Blok, K. (2003) The Direct and Indirect Energy Requirement of Households in the European Union. Energy Policy, 3, 139-153. https://doi.org/10.1016/S0301-4215(02)00019-8

[21] Chudley, R. (2008) Building Construction Handbook. 7th Edition, Elsevier Ltd., Oxford.

[22] Rothley (2012) GEN UKI. http://www.genuki.org.uk/big/eng/LEI/Rothley/index.html

[23] Hitchin, E.R., Holmes, M.J., Hutt, B.C., Irving, S. and Nevrala, D. (1983) The CIBSE Example Weather Year. Building Services Engineering, Research \& Technology, 4(3), 119-124. https://doi.org/10.1177/014362448300400306

[24] Auliciems, A. and Szokolay, S. (2007) Thermal Comfort. 2nd Revised Edition, Brisbane, PLEA: Passive and Low Energy Architecture International in association with Department of Architecture, The University of Queensland.

[25] American Society of Heating, Refrigerating and Air-Conditioning Engineers (ASHRAE) (2009) ASHRAE Handbook-Fundamentals. ASHRAE, Atlanta.

[26] Liddament, M.A. (1996) Guide to Energy Efficient Ventilation. Air Infiltration and Ventilation Centre, Coventry.

[27] Current Carbon Dioxide Levels at Mauna Loa Observatory. Hawaii. http://www.co2now.org

[28] Godoy-Shimizu, D., Armitage, P., Steemers, K. and Chenvidyakarn, T. (2011) Using Display Energy Certificates to Quantify Schools' Energy Consumption. Building Research \& Information, 39(6), 535-552.

https://doi.org/10.1080/09613218.2011.628457 